\title{
Trophic Transfer of Trace Elements in an Isotopically Constructed Food Chain From a Semi-enclosed Marine Coastal Area (Stagnone di Marsala, Sicily, Mediterranean)
}

\author{
Salvatrice Vizzini • Valentina Costa • \\ Cecilia Tramati · Paola Gianguzza • \\ Antonio Mazzola
}

Received: 13 December 2012/Accepted: 10 June 2013/Published online: 12 July 2013

(c) Springer Science+Business Media New York 2013

\begin{abstract}
Trace element accumulation is particularly important in coastal and transitional environments, which act as contaminant buffers between the continental and marine systems. We compared trace element transfer to the biota in two locations with different open-sea exposures in a semi-enclosed marine coastal area (Stagnone di Marsala, Sicily, Italy) using isotopically reconstructed food chains. Samples of sediment, macroalgae, seagrasses, invertebrates, fish, and bird feathers were sampled in July 2006 and analysed for stable carbon and nitrogen isotopes $\left(\delta^{13} \mathrm{C}\right.$, $\delta^{15} \mathrm{~N}$ ) and trace elements (arsenic [As], cadmium [Cd], total mercury [THg], and lead [Pb]). Trophic magnification factors were calculated through the relationships between trace elements and $\delta^{15} \mathrm{~N}$ in consumers. As and $\mathrm{Pb}$ were greater in organic matter sources (sediments and primary producers), whereas $\mathrm{Cd}$ and $\mathrm{THg}$ were greater in bird feathers. At the food chain level, an insignificant trophic transfer was found for all elements, suggesting biodilution rather than biomagnification. Sediments were more contaminated in the location with lower open-sea exposure. Macroalgae and seagrasses overall mirrored the spatial pattern highlighted in sediments, whereas differences between the two locations became further decreased moving toward higher trophic levels, indicating that trophic transfer of sediment and macrophyte-bound trace elements to the coastal lagoon food chain may be of relatively minor importance.
\end{abstract}

S. Vizzini $(\varangle) \cdot$ V. Costa $\cdot$ C. Tramati · P. Gianguzza

A. Mazzola

Dipartimento di Scienze della Terra e del Mare, CoNISMa,

Università degli Studi di Palermo, via Archirafi 18,

90123 Palermo, Italy

e-mail: salvatrice.vizzini@unipa.it
Marine coastal areas are ecosystems of great ecological value due to their high productivity and their roles as nurseries for fish and in staging during bird migration. They are characterized by complex interactions among multiple factors, including abiotic, biotic, and anthropic. Naturally unstable environmental features due to shallowness and confinement from the open-sea produce stressful conditions (Reizopoulou and Nicolaidou 2004). In addition, the geographical continuity with terrestrial ecosystems determines continual exchange and transfer of organic and inorganic materials, thus often resulting in accumulation of organic matter (OM) and pollutants as well as alteration to the natural equilibrium (De Lacerda 1994). In particular, coastal basins act as buffers between the continental and open-sea systems retaining contaminants from different sources (industrial, domestic, and agricultural). As a consequence, these systems are often heavily impacted by human activities.

Among the anthropogenic contaminants, trace elements are of the greatest environmental concern (De Lacerda 1994). A number of metals are naturally present in seawater and marine sediments, and, although several elements are known to be essential to marine organisms (e.g., copper $[\mathrm{Cu}]$ and zinc $[\mathrm{Zn}])$, they are all toxic above certain threshold bioavailable levels. Human activities have dramatically increased levels of trace elements, and considerable attention has been focused on their adverse effects on aquatic ecosystems. Trace elements from both natural and contaminated sources tend to concentrate in aquatic organisms, and some can be transferred up through the food chain by way of biomagnification. Consequent risk to the health of humans, as top-level predators, means the study of biomagnification is increasingly important (Wang 2002). 
Because trophic relationships in marine coastal ecosystems are complex, involving numerous species and links, evaluation of trophic transfer of trace elements within the food chain is highly complicated (Wang 2002). The use of stable carbon and nitrogen isotope $\left(\delta^{13} \mathrm{C}, \delta^{15} \mathrm{~N}\right)$ analysis has allowed greater clarification of trophic relationships and food web structure, thus providing insight into the biomagnification of contaminants (Cheung and Wang 2008). $\delta^{13} \mathrm{C}$ is generally used to provide information on habitat use and carbon sources, whereas $\delta^{15} \mathrm{~N}$ can be used to estimate the trophic position of consumers (Peterson 1999; Post 2002).

Because contaminant level in biota is often significantly correlated with $\delta^{15} \mathrm{~N}$ content, $\delta^{15} \mathrm{~N}$ analysis has recently been combined with pollutant determination (i.e., trace elements, chlorinated hydrocarbons, and polychlorobiphenyls) in several ecosystem components (primary producers and consumers) to assess bioaccumulation and biomagnification processes (e.g., Nfon et al. 2009).

The present study examines the biomagnification potential of a number of trace elements in the food chain of a semi-enclosed marine coastal area (Stagnone di Marsala, Sicily, Italy). Although located in an anthropized context, this area is of great interest due to its high naturalistic value, included, as it is, in the list of Sites of Community Importance (Directive 92/43/CEE; ITA010026) and of Special Protection Areas (Directive 79/409/EEC; ITA010028). As frequently found in marine coastal areas, diverse, multiple sources and anthropic activities may all be responsible for contaminant input in the Stagnone di Marsala, including intensive cultivation, the Birgi watercourse, the nearby civil and military airports, as well as the urbanisation of the area. We analysed trace element (arsenic [As], cadmium [Cd], total mercury $[\mathrm{THg}]$, and lead $[\mathrm{Pb}]$ ) transfer in two sites with different open-sea exposures using isotopically constructed food chains and magnification factors (Food Web Magnification Factor [FWMF]; Trophic Magnification Factor [TMF]). Given that coastal basins function as traps for fine sediment and pollutants, we hypothesised that trace elements tend to accumulate in the central area, which is subject to lower wave action.

\section{Materials and Methods}

Study Area and Sampling Locations

The study was performed in the Stagnone di Marsala, a $20-\mathrm{km}^{2}$ semi-enclosed coastal basin with lagoonal features in Western Sicily $\left(37^{\circ} 52^{\prime} \mathrm{N}, 12^{\circ} 27^{\prime} \mathrm{E}\right.$; Fig. 1$)$. The basin is characterized by shallow water (on average $1.5-\mathrm{m}$ deep) and connected with the adjacent Mediterranean Sea by two channels that allow water circulation, one to the North (400-m wide, 0.3 to $0.4 \mathrm{~m}$ deep) and the other to the South (1200-m wide, 1.0 to $2.0 \mathrm{~m}$ deep). The Central-Northern part of the Stagnone basin is shallower and has a narrower communication with the adjoining sea compared with the Southern part, which is deeper and wider. This morphology, together with wind action, determines turbulent conditions and lower water exchange in the Central-Northern part of the basin and greater water exchange and open-sea vivification in the Southern part (La Loggia et al. 2004).

Considering this geomorphological subdivision of the basin, sampling was performed in two locations characterised by different exposure to the open-sea: one in the central area (hereafter called Centre) and the other in the Southern area (hereafter called South) (Fig. 1). Both locations are characterised by almost similar depth ( 0.6 and $0.8 \mathrm{~m}$ in Centre and South, respectively) and sandy-muddy sediments covered by the dominant macrophyte Cymodocea nodosa (Ucria) Ascherson associated with patches of Posidonia oceanica L. Delile.

\section{Sample Collection and Processing}

Samples of sediment, macrophytes, invertebrates, fish, and bird feathers were collected in July 2006. Hand corers



Fig. 1 Map of the study area with sampling locations 
(internal diameter $4 \mathrm{~cm}$ ) were used to sample sediments (three cores per location), whereas thalli and leaves of macroalgae and seagrasses, respectively, were collected by hand. Epifauna associated with seagrass leaves, which in previous studies (Vizzini et al. 2002; Vizzini and Mazzola 2006) were recognized to play a major trophic role in the system, were caught with a hand-towed net (mesh size $400 \mu \mathrm{m})$.

Small sized-fish (resident and juvenile transient species) were sampled using a small hand-towed trawl net (length $3.5 \mathrm{~m}$; mesh size $3 \mathrm{~mm}$ ) and large-sized ones (adult transient fish) with a trammel net (length $10 \mathrm{~m}$; mesh size $4.3-17 \mathrm{~cm})$. Fishes were classified into estuarine use functional groups (i.e., resident and transient) according to Franco et al. (2008). Due to their greater swimming ability and mobility compared with resident fish, adult transient fish were collected in random sites within the Stagnone di Marsala basin and considered as descriptors that integrate information from the whole area. Bird breast feathers were collected throughout the study area because these are more representative of exposure to metals than other feathers (Burger 1993). All samples were immediately transported to the laboratory in refrigerated containers.

The first centimeter of sediment was isolated in the laboratory for both stable isotope and trace element analysis. Macroalgae [Caulerpa prolifera (Forsskål) Lamouroux 1809, Cladophora sp., Cystoseira spp., Dictyota spp., Laurencia obtusa (Hudson) Lamouroux 1813, Polysiphonia sp., Rytiphlaea tinctoria (Clemente) Agardh 1824] and seagrasses ( $C$. nodosa and $P$. oceanica) were gently scraped to remove epiphytes. Only erect macroalgae were sorted from total epiphytes and analysed.

Crustaceans and polychaetes were the major groups found in epifauna samples. They were identified as to species and family levels, respectively. The required biomass for both isotopic and trace element analysis was obtained for only a few taxa as follows: among the crustaceans, the amphipods Gammarus aequicauda Martynov 1931 and Lysianassa longicornis Ruffo 1987, the tanaid Leptochelia savignyi Kroyer 1842, and the isopod Cymodoce truncata Leach 1814; and among the polychaetes, the families Dorvilleidae, Nereididae, and Syllidae. Invertebrates were left overnight in filtered seawater $(0.45 \mu \mathrm{m})$ to allow gut evacuation.

Fish were identified as to species level and classified into functional guilds (resident fish: Aphanius fasciatus Valenciennes 1821, Atherina boyeri Risso 1810, Pomatoschistus tortonesei Miller 1969, and Syngnathus abaster Risso 1827; transient fish: Chelon labrosus Risso 1827, Liza aurata Risso 1810, L. ramada Risso 1827, L. saliens Risso 1810, and Mugil cephalus L. 1758). Standard length (SL) was recorded.

Feathers were identified as belonging to grey heron (Ardea cinerea L. 1758), yellow-legged gull (Larus michahellis Naumann 1840), and great cormorant (Phalacrocorax carbo L. 1758). They were vigorously washed with Milli-Q deionized water to remove any external contamination and, exclusively for trace element determination, also washed with acetone and then with Milli-Q deionized water by ultrasonic treatment $(44 \mathrm{kHz}, 1 \mathrm{~min})$ according to Eeva et al. (2006) and Szép et al. (2003).

Before isotope and trace element analysis, all samples were oven dried (60 and $40{ }^{\circ} \mathrm{C}$, respectively) and ground to a fine powder using a mortar and pestle. Both isotopic and trace element analyses were performed in triplicate. Each replicate consisted of a pool of 10 and 2-3 individuals for invertebrates and fish, respectively, and of 5 feathers for birds.

Stable Isotope Analysis

$\delta^{13} \mathrm{C}$ and $\delta^{15} \mathrm{~N}$ were analysed separately. Previous to $\delta^{13} \mathrm{C}$ analysis, samples were treated with $\mathrm{HCl} 1 \mathrm{~N}$ to remove carbonates (Carabel et al. 2006). Whole animal was analysed for invertebrates, whereas only dorsal muscle was processed for fish.

$\delta^{13 \mathrm{C}}$ and $\delta^{15} \mathrm{~N}$ were analysed in an isotope ratio mass spectrometer (Thermo Scientific Delta Plus XP) connected to an elemental analyzer (Thermo Scientific Flash EA 1112). Isotopic values were expressed in conventional $\delta$ unit notation, as parts/mil deviations from international standards, i.e., Vienna Pee Dee Belemnite carbonate and atmospheric nitrogen $\left(\mathrm{N}_{2}\right)$ for carbon and nitrogen, respectively, according to the formula: $\delta \mathrm{X}=\left[\left(\mathrm{R}_{\text {sample }} / \mathrm{R}_{\text {standard }}\right)-1\right] \times 10^{3}$, where $X$ is ${ }^{13} \mathrm{C}$ or ${ }^{15} \mathrm{~N}$, and $R$ is the corresponding ${ }^{13} \mathrm{C} /{ }^{12} \mathrm{C}$ or ${ }^{15} \mathrm{~N} /{ }^{14} \mathrm{~N}$ ratio. Analytical precision based on the SD of replicates of internal standards (International Atomic Energy Agency IAEA-NO-3 for $\delta^{15} \mathrm{~N}$ and IAEA-CH- 6 for $\delta^{13} \mathrm{C}$ ) was $0.2 \%$ for both $\delta^{13} \mathrm{C}$ and $\delta^{15} \mathrm{~N}$.

\section{Trace Element Analysis}

The trace elements determined were: $\mathrm{As}, \mathrm{Cd}, \mathrm{THg}$, and $\mathrm{Pb}$. A Varian Vista MPX inductively coupled plasma-optical emission spectrometer was used to analyse samples digested in a CEM MARS microwave oven. Biological samples were mineralized in Teflon digestion vessels with a mixture of $\mathrm{HNO}_{3}, \mathrm{H}_{2} \mathrm{O}_{2}$, and Milli-Q deionized water (Vizzini et al. 2010), whereas sediments were mineralized with $\mathrm{HNO}_{3}, \mathrm{HF}, \mathrm{H}_{2} \mathrm{O}_{2}$, and Milli-Q deionized water (Method 3052, United States Environmental Protection Agency 1996). After cooling, each sample was transferred to a volumetric flask and diluted with distilled water. For each cycle of mineralization, an analytical blank was prepared. The analytical procedure was checked using a standard reference material: dogfish muscle DORM-2 (National Research Council of Canada, NRCC) for fish, 
invertebrates, and feathers (recovery $=90 \%$ for As, $98 \%$ for $\mathrm{Cd}$ and $\mathrm{Hg}$, and $95 \%$ for $\mathrm{Pb})$, Lagarosiphon major BCR-060 (Community Bureau of Reference, CBR) for macrophytes (recovery $=98,97$, and $94 \%$ for $\mathrm{Cd}, \mathrm{Hg}$, and $\mathrm{Pb}$, respectively), and Marine Sediment MESS-3 (NRCC) for sediment (recovery $=94 \%$ for As and $98 \%$ for $\mathrm{Cd}, \mathrm{Hg}$, and $\mathrm{Pb}$ ). Concentrations of As and $\mathrm{THg}$ were determined using a hydride generation system (VGA-77 linked to a ICP-OES). All reagents were Suprapur grade. Results were given in $\mathrm{mg} \mathrm{kg}^{-1}$ dry weight (dw).

\section{Data Elaboration}

To estimate the trophic level (TL) of consumers, the following equation was used: $\mathrm{TL}_{\mathrm{c}}=\left[\left(\delta^{15} \mathrm{~N}_{\mathrm{c}}-\delta^{15} \mathrm{~N}_{\mathrm{ref}}\right) /\right.$ f] $+\mathrm{TL}_{\text {ref }}$, where $\delta^{15} \mathrm{~N}_{\text {ref }}$ and $\mathrm{TL}_{\text {ref }}$ are the stable nitrogen isotope signature and the TL, respectively, of a baseline reference; and $\mathrm{f}$ is the expected $\delta^{15} \mathrm{~N}$ isotopic fractionation per TL (3.4 according to Post 2002). C. truncata, G. aequicauda, and $L$. savignyi were used as baseline references due to their feeding mode as detritivores as acknowledged in the literature (Holdich and Jones 1983; Arrontes 1990; Lepoint et al. 2006) and their low $\delta^{15} \mathrm{~N}$. Averaged $\delta^{15} \mathrm{~N}$ values of the three species were used in each location, and their trophic level was considered as two. Consumers were classified as primary consumers (TL range 1.6-2.5), secondary consumers (TL range 2.6-3.5), tertiary consumers (TL range 3.6-4.5), and top predators (TL > 4.5).

Differences in $\delta^{13} \mathrm{C}, \delta^{15} \mathrm{~N}$, and trace elements between locations for sedimentary OM, macroalgae, seagrasses, and primary and secondary consumers were tested using Mann-Whitney $U$ test. Tertiary consumers and top predators were not tested because most species were representative of the whole area (see Sample Collection and Processing).

Trace element concentrations in macroalgae, seagrasses, invertebrates, fish, and bird feathers were log-transformed, then simple linear regressions were performed for each location using trophic level as the independent variable and trace element content as the dependent variable to establish trophic transfer of trace elements in the food chain. Species representative of the whole area were used for both locations. The slope (b) of the regression-log[trace element $]=\mathrm{a}+\mathrm{b} \times \delta^{15} \mathrm{~N}$-is the biomagnification power (i.e., food web magnification factor [FWMF]; Dehn et al. 2006) of the trace element and represents the change in concentration per unit change in $\delta^{15} \mathrm{~N}$ over the food chain. A positive slope indicates biomagnification, whereas a negative slope indicates trophic dilution. Trophic magnification factors (TMFs) values were calculated from the slope according to the following formula: $\mathrm{TMF}=10^{\mathrm{b}}$ (Nfon et al. 2009). TMF $>1$ indicates accumulation of the trace element in the food chain, whereas a value $<1$ suggests its dilution.

\section{Results}

Stable Isotopes

The organic matter sources (OMS) showed a wide range of $\delta^{13} \mathrm{C}$ that was similar in the two locations: from $-16.2 \pm 2.8 \%$ o (mean \pm SD throughout the section) and $-16.6 \pm 3.1 \%$ in macroalgae to $-9.7 \pm 1.4 \%$ and $-9.9 \pm 0.8 \%$ in seagrasses in South and Centre, respectively (Table 1; Fig. 2). $\delta^{15} \mathrm{~N}$ values fell within a narrower range, i.e., from $1.3 \pm 0.1 \%$ and $0.7 \pm 0.0 \%$ in sedimentary organic matter (SOM) to $4.1 \pm 1.6 \%$ and $4.3 \pm 1.9 \%$ in macroalgae in South and Centre, respectively. Thus, grouping the OMS into macroalgae (including epiphytic erect), seagrasses, and SOM, the same isotopic trend was shown in both locations: on average macroalgae were more ${ }^{13} \mathrm{C}$-depleted than $\mathrm{SOM}$ and seagrasses, and $\mathrm{SOM}$ was more ${ }^{15} \mathrm{~N}$-depleted than macroalgae and seagrasses. Comparing locations, $\delta^{13} \mathrm{C}$ and $\delta^{15} \mathrm{~N}$ in SOM and $\delta^{15} \mathrm{~N}$ in seagrasses were significantly different (MannWhitney $U$ test $p \leq 0.05$ ): both OMS were more ${ }^{15} \mathrm{~N}$ enriched in South than Centre and SOM was more ${ }^{13} \mathrm{C}$ enriched in Centre than South.

In invertebrates, $\delta^{13} \mathrm{C}$ ranged by approximately $7 \%$ units, i.e., from $-10.0 \pm 0.3 \%$ and $-9.3 \pm 0.2 \%$ in C. truncata to $-17.6 \pm 0.3 \%$ in Polychaeta Dorvilleidae, and $-16.1 \pm 0.3 \%$ in L. longicornis in South and Centre, respectively (Table 1). As for OMS, $\delta^{15} \mathrm{~N}$ was less variable, ranging from $3.3 \pm 0.2 \%$ and $2.5 \pm 0.1 \%$ in L. savignyi to $7.7 \pm 0.4 \%$ and $6.9 \pm 0.8 \%$ in Polychaeta Syllidae in South and Centre, respectively. According to their $\delta^{15} \mathrm{~N}$ values, invertebrates were classified as primary (C. truncata, G. aequicauda, L. savignyi, Polycheta Dorvilleidae, and Nereididae) (TL range 1.6-2.5) and secondary consumers (L. longicornis and Polychaeta Syllidae) (TL range 2.6-3.5).

Resident fish showed high $\delta^{13} \mathrm{C}$ variability between locations (Table 1). Fish from South were more ${ }^{13} \mathrm{C}$ depleted by approximately $3 \%$ than those from Centre. In more detail, $\delta^{13} \mathrm{C}$ ranged from $-14.2 \pm 0.2 \%$ in $P$. tortonesei to $-12.5 \pm 0.3 \%$ in A. boyeri in South and from $-10.8 \pm 0.1 \%$ in P. tortonesei to $-9.0 \pm 0.3 \%$ in $S$. abaster in Centre. $\delta^{15} \mathrm{~N}$ ranges were more restricted in both locations, varying from $7.3 \pm 0.1 \%$ in $S$. abaster to $8.5 \pm 0.2 \%$ in $P$. tortonesei in South and from $7.3 \pm 1.1 \%$ in S. abaster to $9.0 \pm 0.5 \%$ in P. tortonesei in Centre. Among transient fish, juveniles were more ${ }^{13} \mathrm{C}$ enriched and ${ }^{15} \mathrm{~N}$-depleted (average $\delta^{13} \mathrm{C}:-11.9 \pm 2.0 \%$, average $\delta^{15} \mathrm{~N}: 7.6 \pm 0.3 \%$ ) than adults (average $\delta^{13} \mathrm{C}$ : 







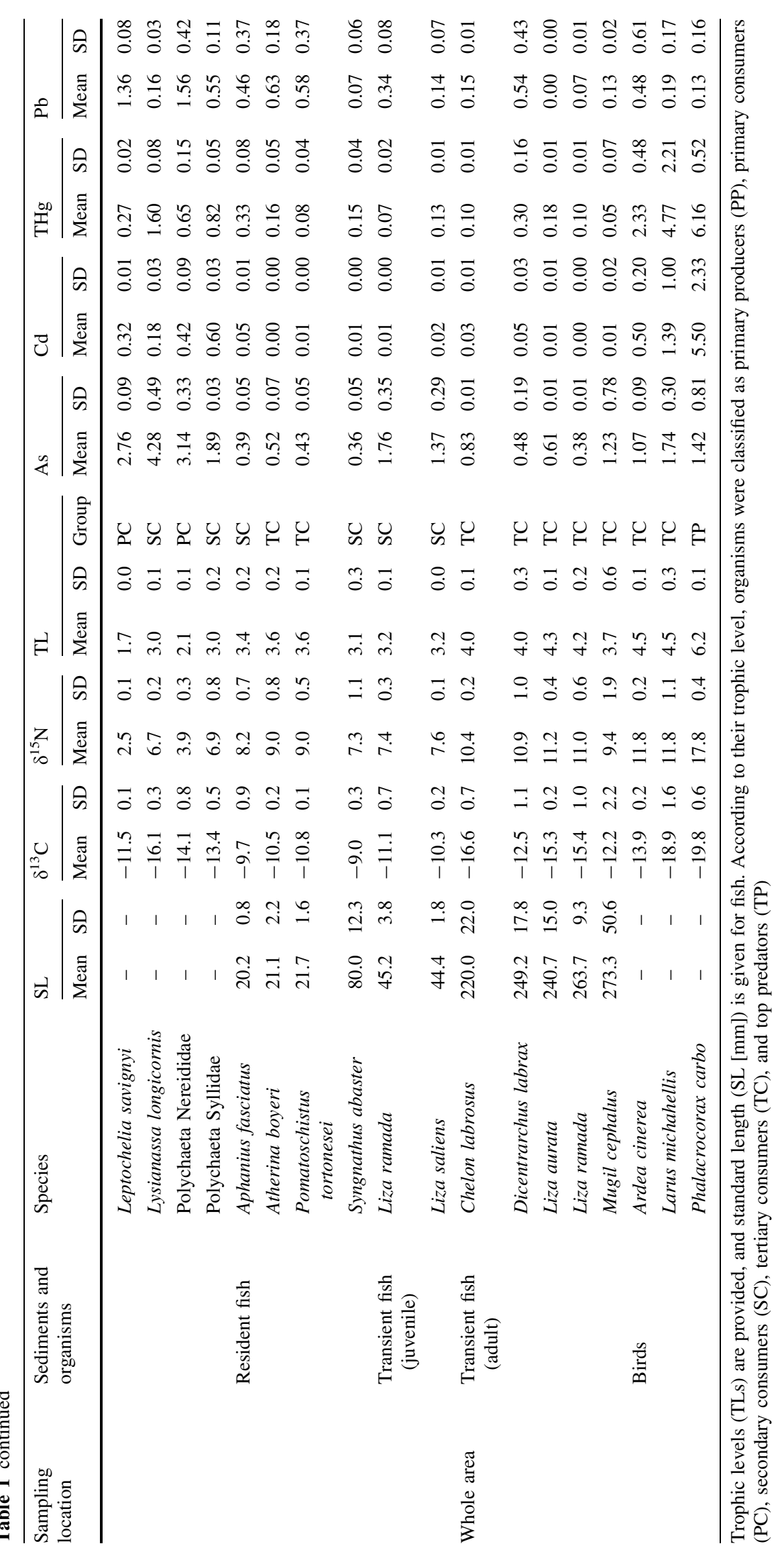



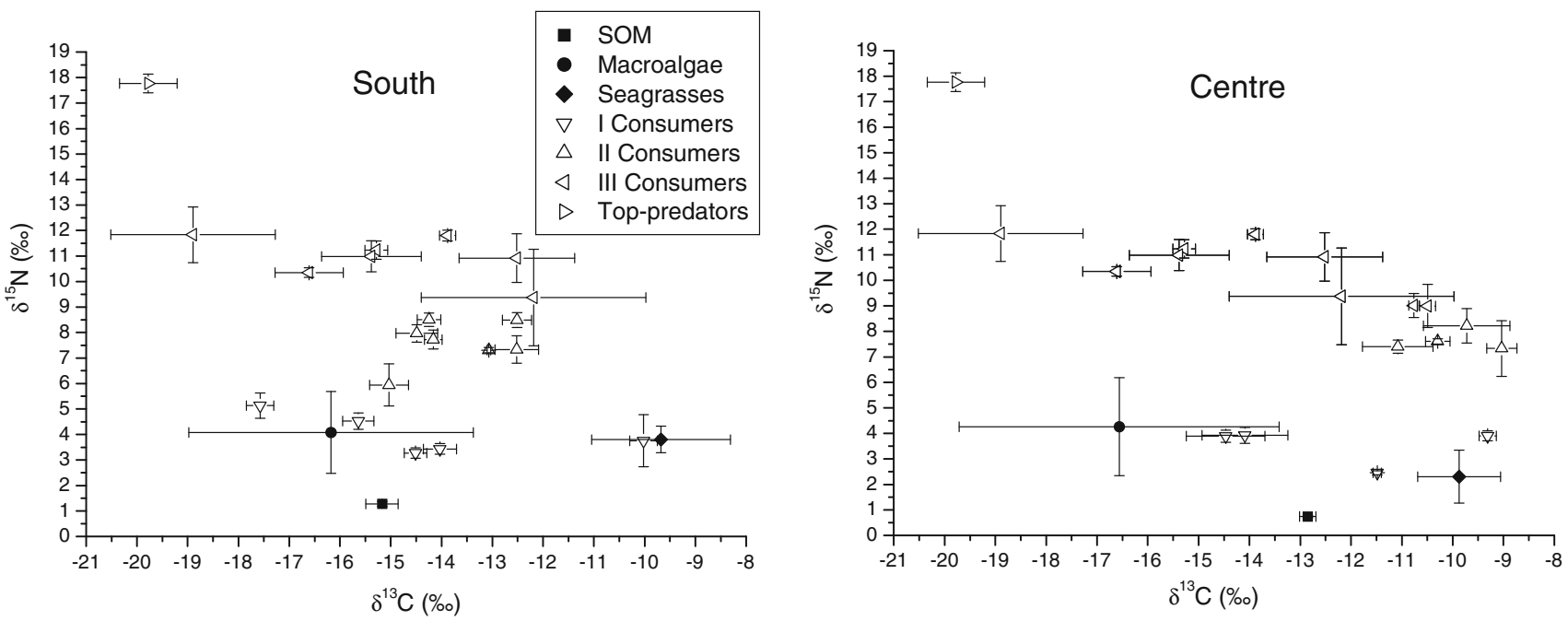

Fig. $2 \delta^{13} \mathrm{C}$ and $\delta^{15} \mathrm{~N}$ values (mean $\pm \mathrm{SD}$ ) for food web components in South and Centre sampling locations. Species classified as I, II, and III consumers and top predators are listed in Table 1. SOM sedimentary organic matter

$-14.1 \pm 2.1 \%$, average $\delta^{15} \mathrm{~N}: 10.6 \pm 1.1 \%$ ). According to their $\delta^{15} \mathrm{~N}$ values, resident and transient juvenile fish were classified as secondary consumers (TL range 2.6-3.5) with the exception of $A$. boyeri and $P$. tortonesei, which were to tertiary consumers (TL range 3.6-4.5) in Centre. Both primary and secondary consumers were significantly more ${ }^{13} \mathrm{C}$-enriched in Centre than in South (Mann-Whitney $U$ test $p \leq 0.05$ and $p \leq 0.01$, respectively).

Bird feathers showed a wide range of carbon isotopic signatures, varying from $-19.8 \pm 0.6 \%$ in $P$. carbo to $-13.9 \pm 0.2 \%$ in A. cinerea (Table 1 ; Fig. 2). $\delta^{15} \mathrm{~N}$ was fairly constant in $A$. cinerea and $L$. michahellis $(11.8 \pm 0.2 \%$ and $11.8 \pm 1.1 \%$, respectively) but markedly lower than in $P$. carbo $(17.8 \pm 0.4 \%)$. Accordingly, A. cinerea and L. michahellis were assigned to tertiary consumers (TL range 3.6-4.5), whereas $P$. carbo was considered a top predator ( $\mathrm{TL}>4.5$ ).

\section{Trace Elements}

The levels of As (minimum mean value $=0.78 \pm$ $0.45 \mathrm{mg} \mathrm{kg}^{-1} \mathrm{dw}$ in tertiary consumers from Centre; maximum mean value $=14.80 \pm 10.42 \mathrm{mg} \mathrm{kg}^{-1} \mathrm{dw}$ in macroalgae from South) and $\mathrm{Pb}$ (minimum mean value $=0.13 \pm$ $0.16 \mathrm{mg} \mathrm{kg}^{-1} \mathrm{dw}$ in top predators; maximum mean value $=18.15 \pm 21.58 \mathrm{mg} \mathrm{kg}^{-1} \mathrm{dw}$ in seagrasses from Centre) were much greater in OMS than in consumers (Table 1; Fig. 3). Cd and THg showed a peak in top predators (e.g., P. carbo) $\left(5.49 \pm 2.33\right.$ and $6.15 \pm 0.52 \mathrm{mg} \mathrm{kg}^{-1} \mathrm{dw}$, respectively). Consistently lower values were shown by the other components (minimum $\mathrm{Cd}=-0.11 \pm 0.21$ $\mathrm{mg} \mathrm{kg}^{-1} \mathrm{dw}$ in secondary consumers from Centre; minimum $\mathrm{THg}=0.15 \pm 0.03 \mathrm{mg} \mathrm{kg}^{-1} \mathrm{dw}$ in sediment from South) apart from $\mathrm{Cd}$ in seagrasses, which showed much greater values $\left(0.99 \pm 0.74\right.$ and $2.13 \pm 2.38 \mathrm{mg} \mathrm{kg}^{-1} \mathrm{dw}$ in South and Centre, respectively). Among macroalgae and seagrasses, wider variation and greater between-species variability were found compared with consumers (Table 1).

Sediment was more contaminated in terms of three (As, $\mathrm{Cd}, \mathrm{THg}$ ) of the four trace elements in Centre than in South (Mann-Whitney $U$ test $p \leq 0.05$ ). Macroalgae, seagrasses, and primary consumers exhibited significant spatial differences for only As ( $p \leq 0.001, p \leq 0.05$, and $p \leq 0.05$, respectively) and THg ( $p \leq 0.01, p \leq 0.05$, and $p \leq 0.05$, respectively), being more contaminated in Centre than in South with the exception of As in macroalgae and $\mathrm{THg}$ in primary consumers, which showed the opposite trend. Differences between the two locations became further reduced on moving toward secondary consumers, which did not show any significant difference.

The relationship between trophic level and trace element concentrations showed clear trophic level-dependent patterns. As, $\mathrm{Cd}$, and $\mathrm{Pb}$ were identified as decreasing with increasing trophic level (Table 2), although the correlation coefficient was lower for $\mathrm{Cd}(R=-0.28$, $p<0.01, N=93$ and $R=-0.25, p<0.05, N=84$ in South and Centre, respectively) than for As $(R=-0.74$, $p<0.001, N=93$ and $R=-0.73, p<0.001, N=84)$ and $\mathrm{Pb}(R=-0.67, p<0.001, N=93$ and $R=-0.71$, $p<0.001, N=84)$. The slope representing FWMF was $-0.3 /-0.4$ for $\mathrm{As}$ and $\mathrm{Pb}$ and lower for $\mathrm{Cd}$ and especially THg. TMF varied from 0.46 and 0.40 for $\mathrm{Pb}$ to 1.06 and 0.89 for THg in South and Centre respectively. Regression analysis was then performed without top predator $P$. carbo (Table 2) because stable isotope analysis showed that this species is not uniquely dependent on the food web analysed. When excluding top predators, the decrease in trace element transfer with increasing trophic level was even 

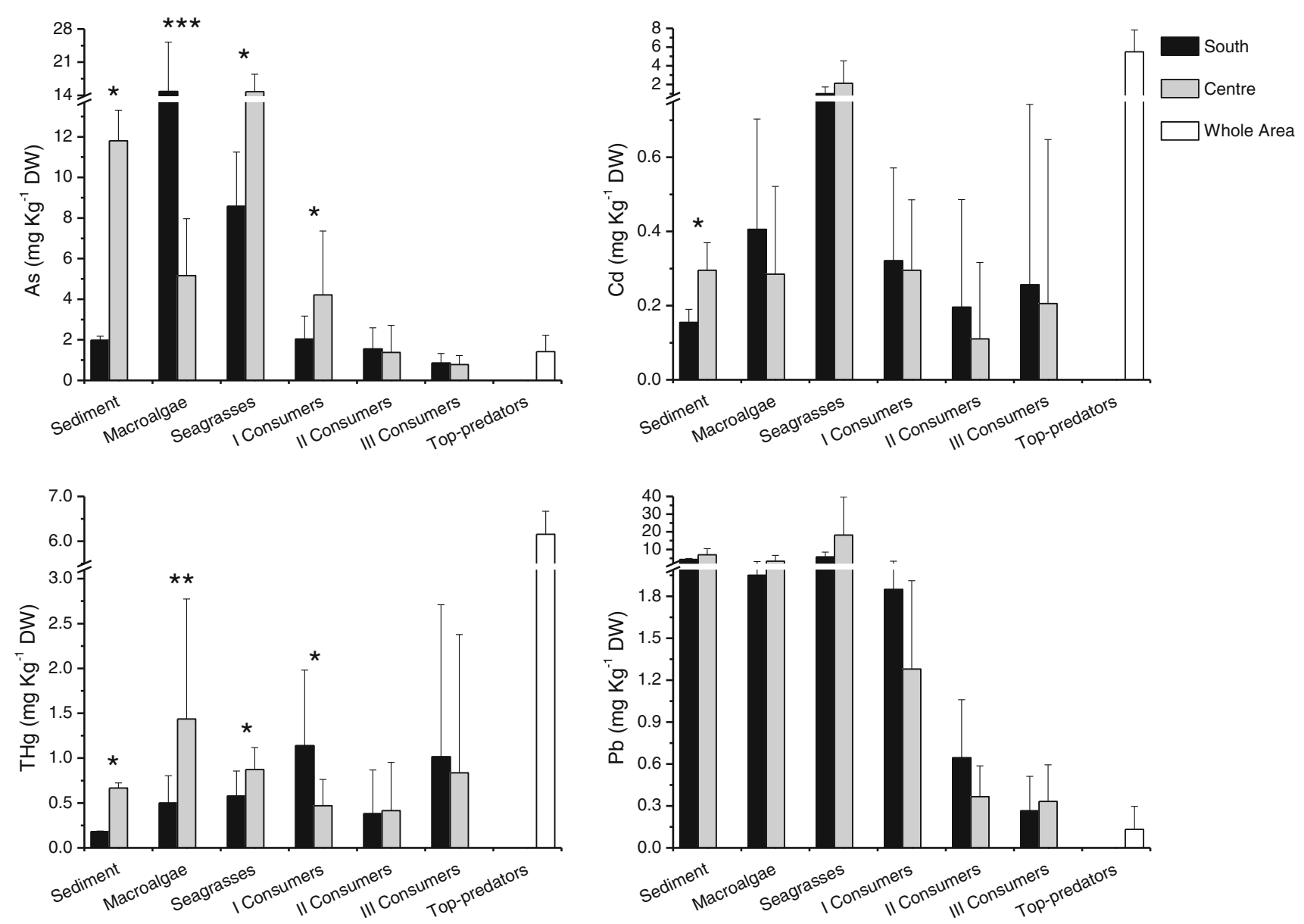

Fig. 3 Trace element concentrations (mean \pm SD) in the different components. Asterisks indicate significant differences between locations using Mann-Whitney $U$ test $(* p \leq 0.05$, **p $\leq 0.01$, and

*** $p \leq 0.001)$. Species classified as I, II, and III consumers and top predators are listed in Table 1

more marked especially for Cd. Accordingly, both FWMF and TMF decreased. In addition, regression analysis was also significant for THg from Centre, although the correlation coefficient did not reach a high value $(R=-0.35$, $p<0.01, N=75$ ).

\section{Discussion}

\section{Stable Isotopes}

An extensive body of literature exists on the trophic structure and pathways of OM in the Stagnone di Marsala (Vizzini et al. 2002; Vizzini and Mazzola 2004, 2005, 2006). In the present study, stable isotope analysis confirmed previous insights on the important role of different sources, including SOM, as basal supply for resident fish in both locations. However, the origin of SOM seems to differ spatially. In South, $\delta^{13} \mathrm{C}$ composition matched that of macroalgae, whereas in Centre it was shifted toward less negative values, approaching those of seagrasses and showing a greater contribution from these primary producers. In $\delta^{15} \mathrm{~N}$ terms, the depleted values of SOM suggest the presence of $\mathrm{N}_{2}$-fixing microorganisms, which generally show low $\delta^{15} \mathrm{~N}$ (close to $0 \%$ ) because low fractionation occurs during nitrogen fixation (Owens 1987). Thus, in agreement with Vizzini and Mazzola (2006), the contribution of SOM and clear overlapping between $\delta^{13} \mathrm{C}$ values of fish and seagrasses make vascular detritus a key trophic component in Centre.

Juvenile transient fish have an isotopic composition that resembles that of resident fish showing similar feeding habits: the former belong to the size class $>4 \mathrm{~cm}$, corresponding to ages at which the shift from zooplanktivorous to benthivorous/detritivorous feeding has already taken place (Ferrari and Chieregato 1981; Gisbert et al. 1996). Accordingly, the SOM/seagrasses-invertebrates-resident/ juvenile transient fish and SOM/macroalgae-invertebratesresident/juvenile transient fish pathways are the most plausible in Centre and South, respectively. 


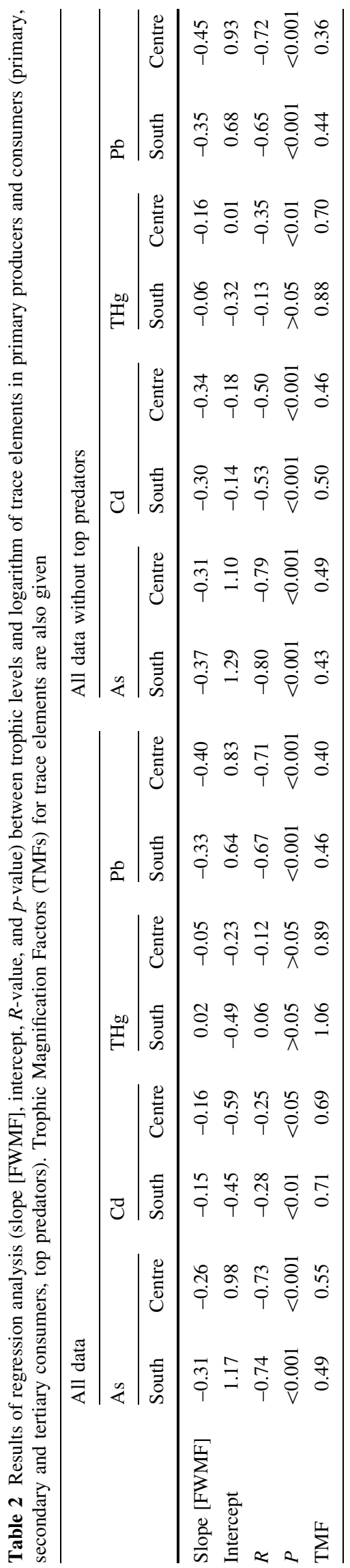

The different role of OMS was previously considered closely dependent on the varying hydrodynamic conditions within the basin. Indeed, the lower hydrodynamism, together with the great accumulation of detritus and $\mathrm{OM}(\mathrm{La}$ Loggia et al. 2004) and the high density of heterotrophic bacteria in the central part of the basin (Mirto et al. 2004), seem to promote a seagrass detritus-based food chain, whereas the greater water exchange with the open-sea in the Southern part triggers a food web based on macroalgae, including epiphytes on seagrass leaves.

Adult transient fish (i.e., Mugilidae and European seabass Dicentrarchus labrax) showed more ${ }^{13} \mathrm{C}$-depleted and ${ }^{15} \mathrm{~N}$-enriched isotopic signatures than resident and juvenile transient fish. Although Mugilidae filter large quantities of sediment, after correction for isotopic fractionation, their isotopic composition does not match that of SOM. This result implies that from the trophic point of view, Mugilidae may depend on prey associated with sediments, which are more ${ }^{13} \mathrm{C}$-depleted and/or ${ }^{15} \mathrm{~N}$-enriched than those sampled in this study.

Both D. labrax and, among birds, A. cinerea had isotopic values that matched well with a diet based on small fish (both resident and transient from South). L. michaellis belonged to similar trophic levels but exploited less enriched sources. Finally, P. carbo was at the top of the food chain, reaching $\delta^{15} \mathrm{~N}$ values of $18 \%$, compatible with the exploitation of nonsampled large carnivores, whereas the role of mugilids and sea bass as prey seems to be less important here than in other coastal areas (Barati 2009; Liordos and Goutner 2009).

\section{Trace Elements}

In coastal areas, sediment is the major compartment for metal storage, acting as a sink for trace metals and supplying time-integrated information about contamination levels (Burton and Scott 1992). Overall trace element levels were comparable with the ranges found in slightly and moderately contaminated Mediterranean lagoons (e.g., Varano lagoon-Italy, Storelli and Marcotrigiano 2001; Berre lagoon-France, Accornero et al. 2008). The contamination found in the study area may be the result of multiple and long-term sources, including input from the Birgi stream close to the Northern opening of the basin, sewage waste from the urban center of Marsala close to the Southern opening, surface runoff from agriculture, atmospheric deposition deriving also from nearby Birgi Airport, and maritime traffic, etc.

The highest values for all trace elements were recorded in the central location, where the extensive seagrass beds coupled with shallowness and low hydrodynamism may promote the entrapment of floating contaminated particulate, thus increasing the sedimentation of trace elements. In 
contrast, in the deeper Southern location, more influenced by open-sea vivification, greater wave action produces greater dilution of contaminants, thus decreasing their sedimentation. The spatial variation in sediment contaminant content seems to be driven also by variation in grain size distribution, which in the Stagnone follows a concentric pattern, with silt and clay more concentrated in the Centre of the basin (Vizzini 2000). As an example, in South, As content showed averaged values lower than the ranges reported for other Mediterranean lagoons (e.g., Nador lagoon-Morocco, Ruiz et al. 2006), whereas in Centre, values were similar to those for contaminated lagoons (e.g., central part of Venice lagoon-Italy, Bellucci et al. 2002). Moreover, As, Cd, and THg showed values approaching or exceeding the Italian regulatory limits (Gazzetta Ufficiale della Repubblica Italiana D.M. 367/03, 2004) (11.8 vs. $12.0,0.3$ vs. 0.3 , and 0.7 vs. $0.3 \mathrm{mg} \mathrm{kg}^{-1} \mathrm{dw}$, respectively) in Centre, whereas in South the values were far lower than these limits.

Estimation of total trace elements in sediments provides a convenient measure of metal pollution, but it does not predict ecosystem quality as does the evaluation of pollutant concentrations in the biota. Overall, primary producers showed greater values than other food web components especially for $\mathrm{As}$ and $\mathrm{Pb}$. In particular, As was greater than in contaminated seagrass ecosystems (e.g., Balearic Islands-Spain, Fourqurean et al. 2007). $\mathrm{Pb}$ in macroalgae was comparable with that of uncontaminated sites (Favignana Island-Italy, Campanella et al. 2001), whereas in seagrasses it was greater than in a slightly contaminated marine-coastal area (port of Favignana Island-Italy, Campanella et al. 2001; Island of Ischia-Italy, SchlacherHoenlinger and Schlacher 1998). THg was remarkably high, especially in Centre, where it showed greater concentrations than in a contaminated marine-coastal area close to a large chemical plant (Rosignano-Italy, Capiomont et al. 2000). Finally, Cd was lower than the mean values reported for macrophytes from contaminated lagoons (e.g., Ruppia maritima and Ulva rigida in Monolimni Lagoon-Greece, Boubonari et al. 2009) and also uncontaminated sites adjoining the study area (e.g., $P$. oceanica and Padina pavonica in Favignana Island-Italy, Campanella et al. 2001). The clear trace element accumulation in primary producers may account for their ability to concentrate a range of elements from the sediments through the dissolved fraction (porewater) or from the surrounding water to leaves, thus decreasing direct metal availability to heterotrophic organisms (e.g., Boubonari et al. 2009). Accordingly, macrophytes seem to function as major pools of trace elements.

Despite the contamination found in macrophytes, primary consumers (i.e., invertebrates) generally exhibited lower levels given that trace elements bound to vegetal cell walls and membranes may be preferentially excreted in faecal pellets rather than assimilated (Reinfelder et al. 1998).

Overall, secondary and tertiary consumers (i.e., mostly fish) showed lower concentrations than primary consumers. A number of factors may explain this result, in particular: (1) benthic invertebrates live closer than fish to sediment and macrophytes, which in the study area are a repository for a large number of contaminants; (2) a large number of invertebrates are known to contain metal-rich granules in which trace elements are sequestered in a detoxified form (Ahearn et al. 2004) and bound to metallothioneins (Mason and Jenkins 1995); (3) trace elements in fish are also determined by a complex physiological and biochemical species-specific process (Barron 1990; Storelli and Marcotrigiano 2001); (4) trace metals in specific tissues may be much greater (e.g., liver generally concentrates metals); (5) as active swimmers, fish integrate and mirror environmental contamination at a broad spatial scale, and this may lead to misestimation of contaminant levels; and (6) organisms at greater trophic levels may exhibit more efficient excretion of certain elements (Watanabe et al. 2008).

\section{FWMF Values}

Calculation of FWMF values indicates that magnification of trace elements in the food web of the Stagnone di Marsala does not occur. In contrast, concentration of trace elements decreased with increasing trophic level, suggesting that they are biodiluted. The same results were obtained when excluding the top predator $P$. carbo because it is not exclusively dependent on the food web that was reconstructed. The high correlation coefficients for $\mathrm{As}$ and $\mathrm{Pb}$ suggest linearity in the relationship between their concentration and trophic level. In contrast, Cd showed a significant, negative correlation but a low $R$ value, thus highlighting a lack of linearity.

Although As (Suedel et al. 1994), Cd (Dietz et al. 2000; Cheung and Wang 2008) and especially Hg (Dietz et al. 2000; Ikemoto et al. 2008) are acknowledged to have biomagnification potential, this process is not obvious. There are also cases where there is a lack of trace metal increase along marine food webs (Dietz et al. 2000; Dehn et al. 2006; Marín-Guirao et al. 2008), probably due to the low assimilation efficiencies and high efflux rates of trace metals in marine organisms, which decreases their potential for biomagnification (Wang 2002). Conversely to $\mathrm{As}, \mathrm{Cd}$, and $\mathrm{Hg}$, and in agreement with our results, $\mathrm{Pb}$ is known not to be transferred efficiently through marine food webs (Neff 2002).

Although linear regressions are indicative of overall trends in trace elements along food chains, it is worth bearing in mind that calculation of FWMF values requires a number of assumptions that may not hold true for trace metals (Dehn et al. 2006). These assumptions include that 
the contaminant burden of a predator originates from the prey and that the tissue under evaluation is a good proxy for total metal burden. However, metal uptake and adsorption through gills and body surfaces are important exposure pathways for aquatic organisms (Sayeed et al. 2000; Ahlf et al. 2009). In addition, trace metals are generally actively regulated and subject to binding-site competition (McGeer et al. 2003). Furthermore, several physical and biological factors, including geography, sex, age, and body condition, affect metal deposition in animal tissues (Dehn et al. 2006).

The Centre of Stagnone di Marsala was more contaminated in the basal sources (sediments and primary producers) than South, whereas differences between locations became further decreased moving toward higher trophic levels. The same spatial pattern of trophic dilution was observed in the two locations with an insignificant transfer of trace metals, showing that the transfer of sediment and macrophyte-bound trace elements to the coastal lagoon food chain may be of relatively minor importance as previously reported elsewhere (Boubonari et al. 2009).

\section{Conclusion}

Insignificant transfer of trace elements in both less and more contaminated locations is an important issue, thus highlighting the importance of environmental features and biological factors associated with both primary producers and consumers in determining trace element bioavailability and trophic transfer in coastal basins. In this study, the contaminant buffer role of coastal basins in preventing horizontal connections of contaminants from the terrestrial boundary to the open-sea is further highlighted, whereas, in agreement with recent literature (e.g., Marín-Guirao et al. 2008; Jara-Marini et al. 2009), biomagnification appears to be an overstated process in lagoonal basins.

Acknowledgments We thank A. Savona for help in the collection of samples, A.E. Aleo for support in stable isotope analysis, and M. Lo Valvo for identification of bird feathers. This study was funded by a PRIN-MIUR Grant and the University of Palermo.

\section{References}

Accornero A, Gnerre R, Manfra L (2008) Sediment concentrations of trace metals in the Berre lagoon (France): an assessment of contamination. Arch Environ Contam Toxicol 54:372-385

Ahearn GA, Mandal PK, Mandal A (2004) Mechanisms of heavymetal sequestration and detoxification in crustaceans: a review. J Comp Physiol B 174:439-452

Ahlf W, Drost W, Heise S (2009) Incorporation of metal bioavailability into regulatory frameworks-metal exposure in water and sediment. J Soils Sed 9:411-419
Arrontes J (1990) Diet, food preference and digestive efficiency in intertidal isopods inhabiting macroalgae. J Exp Mar Biol Ecol 139:231-249

Barati A (2009) Diet and growth of chicks of the great cormorant, Phalacrocorax carbo, at Ramsar, northern Iran (Ayes: Phalacrocoracidae). Zool Middle East 46:29-36

Barron MG (1990) Bioconcentration: will water-borne organic chemicals accumulate in aquatic animals? Environ Sci Technol 24:1612-1618

Bellucci LG, Frignani M, Paolucci D, Ravanelli M (2002) Distribution of heavy metals in sediments of the Venice Lagoon: the role of the industrial area. Sci Total Environ 295:35-49

Boubonari T, Kevrekidis T, Malea P (2009) Metal (Fe, Zn, Cu, Pb and $\mathrm{Cd}$ ) concentration patterns in components of a macrophyte-based coastal lagoon ecosystem. Hydrobiologia 635:27-36

Burger J (1993) Metals in avian feathers: bioindicators of environmental pollution. Rev Environ Toxicol 5:203-311

Burton GA Jr, Scott KJ (1992) Sediment toxicity evaluations. Environ Sci Technol 26:2068-2075

Campanella L, Conti ME, Cubadda F, Sucapane C (2001) Trace metals in seagrass, algae and molluscs from an uncontaminated area in the Mediterranean. Environ Pollut 111:117-126

Capiomont A, Piazzi L, Pergent G (2000) Seasonal variations of total mercury in foliar tissues of Posidonia oceanica. J Mar Biol Assoc UK 80:1119-1123

Carabel S, Godínez-Domínguez E, Verísimo P, Fernández L, Freire J (2006) An assessment of sample processing methods for stable isotope analyses of marine food webs. J Exp Mar Ecol Biol 336:254-261

Cheung MS, Wang WX (2008) Analyzing biomagnification of metals in different marine food webs using nitrogen isotopes. Mar Pollut Bull 56:2082-2105

De Lacerda LD (1994) Biogeochemistry of heavy metals in coastal lagoons. In: Kjerfve B (ed) Coastal lagoon processes. Elsevier, Amsterdam, pp 221-241

Dehn L, Follmann E, Thomas D, Sheffield G, Rosa C, Duffy L et al (2006) Trophic relationships in an Arctic food web and implications for trace metal transfer. Sci Total Environ 362:103-123

Dietz R, Riget F, Cleemann M, Aarkrog A, Johansen P, Hansen JC (2000) Comparison of contaminants from different trophic levels and ecosystems. Sci Total Environ 245:221-231

Eeva T, Belskii E, Kuranov B (2006) Environmental pollution affects genetic diversity in wild bird populations. Mutat Res Gen Toxicol Eng 608:8-15

Ferrari I, Chieregato AR (1981) Feeding habits of juvenile stages of Sparus auratus L., Dicentrarchus labrax L. and mugilidae in a brackish embayment of the Po river delta. Aquaculture 25:243-257

Fourqurean JW, Marbà N, Duarte CM, Diaz-Almela E, Ruiz-Halpern S (2007) Spatial and temporal variation in the elemental and stable isotopic content of the seagrasses Posidonia oceanica and C. nodosa from the Illes Balears, Spain. Mar Biol 151:219-232

Franco A, Elliott M, Franzoi P, Torricelli P (2008) Life strategies of fishes in European estuaries: the functional guild approach. Mar Ecol Prog Ser 354:219-228

Gazzetta Ufficiale della Repubblica Italiana (GURI) (2004) Regolamento concernente la fissazione di standard di qualità nell'ambiente acquatico per le sostanze pericolose. DM 367/2003. Ministero dell'Ambiente e della Tutela del Territorio, Roma

Gisbert E, Cardona L, Castellò F (1996) Resource partitioning among planktivorous fish larvae and fry in a Mediterranean coastal lagoon. Estuar Coast Shelf Sci 43:723-735

Holdich DM, Jones JA (1983) Tanaids: keys and notes for the identification of the species. Synopsis of the British fauna. Cambridge University Press, Cambridge, UK 
Ikemoto T, Tu NPC, Okuda N, Iwata A, Omori K, Tanabe S et al (2008) Biomagnification of trace elements in the aquatic food web in the Mekong Delta, South Vietnam using stable carbon and nitrogen isotope analysis. Arch Environ Contam Toxicol 54:504-515

Jara-Marini ME, Soto-Jiménez MF, Páez-Osuna F (2009) Trophic relationships and transference of cadmium, copper, lead and zinc in a subtropical coastal lagoon food web from SE Gulf of California. Chemosphere 77:1366-1373

La Loggia G, Calvo S, Ciraolo G, Mazzola A, Pirrotta M, Sarà G et al (2004) Influence of hydrodynamic conditions on the production and fate of Posidonia oceanica in a semi-enclosed shallow basin (Stagnone di Marsala, Western Sicily). Chem Ecol 20:183-201

Lepoint G, Cox AS, Dauby P, Poulicek M, Gobert S (2006) Food sources of two detritivore amphipods associated with the seagrass Posidonia oceanica leaf litter. Mar Biol Res 2:355-365

Liordos V, Goutner V (2009) Sexual differences in the diet of great cormorants Phalacrocorax carbo sinensis wintering in Greece. Eur J Wildlife Res 55:301-308

Marín-Guirao L, Lloret J, Marin A (2008) Carbon and nitrogen stable isotopes and metal concentration in food webs from a miningimpacted coastal lagoon. Sci Total Environ 393:118-130

Mason AZ, Jenkins KD (1995) Metal detoxification in aquatic organisms. In: Tessier A, Turner DR (eds) Metal speciation and bioavailability in aquatic systems. Wiley \& Sons, Chichester, pp 479-608

McGeer JC, Brix KV, Skeaff JM, DeForest DK, Brigham SI, Adams WJ et al (2003) Inverse relationship between bioconcentration factor and exposure concentration for metals: implications for hazard assessment of metals in the aquatic environment. Environ Toxicol Chem 22:1017-1037

Mirto S, La Rosa T, Mocciaro G, Costa K, Sarà G, Mazzola A (2004) Meiofauna and benthic microbial biomass in a semi-enclosed Mediterranean marine system (Stagnone of Marsala, Italy). Chem Ecol 20:387-396

Neff JM (2002) Bioaccumulation in marine organisms. Elsevier, Amsterdam

Nfon E, Cousins I, Järvinen O, Mukherjee A, Verta M, Broman D (2009) Trophodynamics of mercury and other trace elements in a pelagic food chain from the Baltic Sea. Sci Total Environ 407:6267-6274

Owens N (1987) Natural variations in ${ }^{15} \mathrm{~N}$ in the marine environment. Adv Mar Biol 24:389-451

Peterson B (1999) Stable isotopes as tracers of organic matter input and transfer in benthic food webs: a review. Acta Oecol 20:479-487

Post DM (2002) Using stable isotopes to estimate trophic position: models, methods, and assumptions. Ecology 83:703-718

Reinfelder J, Fisher N, Luoma S, Nichols J, Wang W (1998) Trace element trophic transfer in aquatic organisms: a critique of the kinetic model approach. Sci Total Environ 219:117-135

Reizopoulou S, Nicolaidou A (2004) Benthic diversity of coastal brackish-water lagoons in western Greece. Aquat Conserv Mar Freshwater Ecosyst 14:S93-S102
Ruiz F, Abad M, Olias M, Galan E, Gonzalez I, Aguila E et al (2006) The present environmental scenario of the Nador Lagoon (Morocco). Environ Res 102:215-229

Sayeed I, Ahmad I, Fatima M, Hamid T, Islam F, Raisuddin S (2000) Inhibition of brain $\mathrm{Na}^{+}, \mathrm{K}^{+}$-ATPase activity in freshwater catfish (Channa punctatus Bloch) exposed to paper mill effluent. Bull Environ Contam Toxicol 65:161-167

Schlacher-Hoenlinger MA, Schlacher TA (1998) Differential accumulation patterns of heavy metals among the dominant macrophytes of a Mediterranean seagrass meadow. Chemosphere 37:1511-1519

Storelli MM, Marcotrigiano GO (2001) Heavy metal monitoring in fish, bivalve molluscs, water, and sediments from Varano Lagoon, Italy. Bull Environ Contam Toxicol 66:365-370

Suedel BC, Boraczek JA, Peddicord RK, Clifford PA, Dillon TM (1994) Trophic transfer and biomagnification potential of contaminants in aquatic ecosystems. Rev Environ Contam Toxicol 136:21-89

Szép T, Møller AP, Vallner J, Kovács B, Norman D (2003) Use of trace elements in feathers of sand martin Riparia riparia for identifying moulting areas. J Avian Biol 34:307-320

United States Environmental Protection Agency (1996) Method 3052. Microwave assisted acid digestion of siliceous and organically based matrices. USEPA, Washington, DC

Vizzini S (2000) Caratteristiche dei sedimenti in un'area costiera della Sicilia occidentale (Stagnone di Marsala). Biol Mar Medit 7:524-527

Vizzini S, Mazzola A (2004) The trophic structure of the pipefish community (Pisces: Syngnathidae) from a western Mediterranean seagrass meadow based on stable isotope analysis. Estuaries 27:25-333

Vizzini S, Mazzola A (2005) Feeding ecology of the sand smelt Atherina boyeri (Risso 1810) (Osteichthyes, Atherinidae) in the western Mediterranean: Evidence for spatial variability based on stable carbon and nitrogen isotopes. Environ Biol Fishes 72:259-266

Vizzini S, Mazzola A (2006) Sources and transfer of organic matter in food webs of a Mediterranean coastal environment: evidence for spatial variability. Estuar Coast Shelf Sci 66:459-467

Vizzini S, Sarà G, Michener R, Mazzola A (2002) The role and contribution of the seagrass Posidonia oceanica (L.) Delile organic matter for secondary consumers as revealed by carbon and nitrogen stable isotope analysis. Acta Oecol 23:277-285

Vizzini S, Tramati C, Mazzola A (2010) Comparison of stable isotope composition and inorganic and organic contaminant levels in wild and farmed bluefin tuna, Thunnus thynnus, in the Mediterranean Sea. Chemosphere 78:1236-1243

Wang WX (2002) Interactions of trace metals and different marine food chains. Mar Ecol Progr Ser 243:295-309

Watanabe K, Monaghan MT, Takemon Y, Omura T (2008) Biodilution of heavy metals in a stream macroinvertebrate food web: Evidence from stable isotope analysis. Sci Tot Environ 394:57-67 